\title{
Descriptive Qualitative Teaching Method of Memorization in The Institution of Tahfiz Al-Quran Wal Qiraat Pulai Condong and the Students' Level of Academic Excellence
}

\author{
Muhaidi Mustaffa Al Hafiz \\ Muhammad Fathi Yusof \\ Mohd Al'lkhsan Ghazali \\ Siti Salwa Md. Sawari \\ Faculty of Islamic Civilization, University Technology Malaysia
}

Doi:10.5901/mjss.2016.v7n1s1p79

\begin{abstract}
Currently, the existence of Tahfiz institution or Maahad Tahfiz in the Malaysian educational system plays a big role in the development of Quranic studies. The purpose of the establishment of Maahad is to realize the educational philosophy in an integrated manner besides producing huffaz who have skills in all areas. Huffaz who are skilled with the contents of the Quran, knowledgeable, practical, devoted, efficient on the contents of the Quran as well as realizing their knowledge in society has become a major stepping stone. Therefore, the researchers have carried out this study to identify the students' academic excellence report from the institution of Tahfiz al-Quran Wal Qiraat Pulai Chondong and the methods applied in its education and learning process. In this study, the research that will be carried out is more descriptive qualitative (manhaj dirasah wasfiyyah). Descriptive research is generally a research, not an experiment. The results of this study have shown that the majority of the students from MTAQPC have outstanding academic records. The methods used by MTAQPC teachers when teaching the Quranic memorization subject are through correct pronunciation, the use of specific mushaf, regulating the rate of memorization, the recitation of dua' before memorizing and others. The researchers claimed that the memorization of the Quran has given a big impact on the huffaz of the Quran.
\end{abstract}

Keywords: Al-Quran, Huffaz, Memorization, Education.

\section{Introduction}

Allah has sent down the Quran as a revelation to the Prophet Muhammad SAW. It is the greatest miracle bestowed by Allah to His Messenger to guide humankind. This is explained by Allah in the Quran, in Surah Ibrahim verse 1, "Alif Lam Ra .... . (This is) a Book which We have revealed unto you (Muhammad) in order that you might lead mankind out of the depths of darkness into light- by the leave of their Lord- to the Way of (Him) the Exalted in Power, Worthy of all Praise!-".

\footnotetext{
In other Allah's words which means: "O mankind! We have sent down the Messenger (Muhammad SAW) to you who bring the truth that is the guidance from your Lord, so believe, that is better for you. And if you deny (then disbelief does not even harm Allah) because whatever is in the heavens and on the earth belongs to Allah SWT. And Allah is AllKnowing and Wise".
}

Not only that, the Qur'an also become guidance and reference to people from the past until now (Muhaidi, Mohd Al'Ikhsan \& Siti Salwa, 2015b, Ghazali, Md. Sawari \& Yusof, 2015). Al-Quran is the primary source of Islamic law. It plays a role in giving explanation and development towards human daily life on earth. The Quran was revealed by Allah to mankind through the angel Jibril about 14 centuries ago, but it remains the same without any changes. Even its authenticity always guaranteed and preserved by Allah SWT up to this moment. Allah SWT says in Surah al-Hijr, (15): 9 which means, "We have, without doubt, sent down the Message; and We will assuredly guard it (from corruption)".

In the Quran, there are verses which call for the appreciation of the Quran (Yusuf al-Qardawi, n.d). Allah says in Surah Muhammad (47): 24, "Do they not then earnestly seek to understand the Quran, or are their hearts locked up by them?" Allah says in another verse of Surah al-Sad (38): 29, which means: "(Here is) a Book which We have sent down unto you, full of blessings, that they may mediate on its Signs, and that men of understanding may receive admonition".

Muslims are known as people who are always observant in order to preserve the sanctity of the Quran. The efforts 
are made in various forms, including memorization of the Quran word by word and letter by letter (Syaykh Muhammad alHabasyi, 1987). It is one of the efforts to ensure the implementation of some Sunnah of the Prophet s.a.w. that could not be done without the process of memorizing the Quran (Abu Najihat al-Hafiz, n.d).

In Malaysia normally, the term hafiz is given to those who memorize the entire Quran, but the term actually worth to those who memorize the hadith in a large number and know the status of the hadith whether sohih or dhoif. A more appropriate title should be the supporter of the Quran or "hāmil al-Qur'ān". However, whatever title given, their responsibility is to preserve the sanctity of the Quran that has been memorized. Imam Nawawi has said that those who are proficient in the Qur'an are the one who are mature enough in their memorization until they are fluent and easy to read and repeat the Quranic verses wherever they are Abdullah (al-Qari Hj Salleh 1979). Allah SWT says which means "and We have made the Quran easy to warn, then is there anyone who will take the lesson". It also being strengthen by the hadith which means: Those who read the Quran and then memorize it, he will legalize what is halal and forbid what is haram...(Al-Imam al-Hafiz Abi 'Isa Muhammad bin 'Isa bin Surah al-Tirmidhi, 1975).

\section{Tahfiz Al-Quran Institution In Malaysia}

Allah SWT assures that the authenticity of the Qur'an will remain since its revelation until now (Ismail Muhammad alMuqri' \& Khairul Anuar Muhamad al-Bakri, 2003). The first person who got the honour to perform the task of collecting the Quran with its meaning and memorize it by heart is the Prophet Muhammad SAW. Thus, he is considered as a leader or the first person who remembered and memorized the Quran and he encouraged his companions to memorize the Quran every time the revelations were descended upon him. Then, it was followed by the generation of companion, tabi'in, tabi 'tabi'in until today with the establishment of tahfiz institution in Malaysia (Muhaidi, Mohd Al'Ikhsan \& Siti Salwa, 2015).

In Malaysia, tahfiz institutions play a major role in the development of Quranic study especially in Quranic memorization and qira'at. The establishment of tahfiz institutions in Malaysia is to realize the educational philosophy in an integrated manner besides producing huffaz who have skills in all areas. It also aims to produce huffaz who are skilled with the contents of the Quran, knowledgeable, practical, devoted, and efficient on the contents of the Quran as well as realizing their knowledge in society (Muhaidi, Mohd Al'Ikhsan \& Siti Salwa, 2015a).

The existence of MTAQ has helped the government especially the Ministry of Education and the State Religious Council in establishing the Islamic and Quranic studies in an integrated manner with other academic subjects in line with the objective of producing students who can master two areas of the world and the Hereafter, or in other words, master the knowledge of fard 'ain and fard' kifayah.

The existence of MTAQ lately has contributed to some of the excellence record in education due to excellent results obtained by some MTAQ students in the examination conducted by the Ministry of Education. This phenomenon has attracted some people to know what the secrets behind the success are as some people responded that memorization of the Quran (the whole Quran) in the education syllabus is too much and will certainly become a huge academic burden to students and this situation of course, will cause them to not be able to focus in their academic. However, this response seemed not true after the students of MTAQ have proven their ability to success in Quranic memorization as well as achieve excellent results in academic.

Thus, this phenomenon is worth studying academically in order to identify and assess the advantages gained by huffaz of the Quran or synonym in Malaysian community with the title "al-hafiz" who excel in memorizing the Quran and at the same time are able to excel in academic and character. Therefore, this paper proposed a study to be conducted in the institution of Tahfiz Al-Quran Wal Qiraat Pulai Chondong, Kelantan (MTAQPC).

\section{The Objective of the Study}

This study was carried out to achieve several objectives which are:

(1) To identify the academic excellence record of students from the institution of Tahfiz al-Quran Wal Qiraat Pulai Chondong.

(2) To identify the methods used by the institution of Tahfiz al-Quran Wal Qiraat Pulai Chondong in education and learning process.

\section{Methodology}

In this study, the research will be more descriptive qualitative (manhaj dirasah wasfiyyah). Descriptive research is generally a research, not an experiment. It intends to collect information about the status of an existing matter which is 
the matter happened during the time the research was conducted. It does not require administration and control of the behaviour. It also does not test a specific hypothesis, but merely describes "what is" on the variable, matter or condition.

Regarding qualitative, sometimes called as inquiry, naturalistic investigation is used to describe this term. In general, according to Bogdan and Taylor (1975: 5), qualitative methodology means a research procedure that produce descriptive data in the form of written or spoken words of the observed people and behaviour. In line with this definition, Kirk and Miller (1986: 9) has defined that qualitative research is a tradition in social sciences that is fundamentally dependent on the observation of the human being in their own region and people in their own language and terminologies.

Therefore, the methods of collecting data in this study include:

\section{Library Studies}

This research is a descriptive qualitative study which generally focuses on library studies method to obtain the data needed to support and enhance the study. To obtain the amount of data from the library, library research method will be used, by acquiring, reading, analyzing and recording the theories sourced from books, journals, monographs, newsletters and various other printed media publications as resources, to come up with theories that are related and relevant to the issues being investigated. Primary sources will be obtained from MTAQPC, especially the lesson record books (academic achievement), disciplinary record and students' extra-curricular activities record to measure the students' excellence level that combines academic and personality aspects. Records from Kelantan Islamic Foundation (YIK) and the State Department of Education (Ministry of Education) will also be examined for the purpose of assisting the process of measuring the students' level of excellence in that tahfiz institution.

\section{IT (Information Technology) Research}

For reinforcement purpose, some information or additional data will be collected through IT (internet). This will help the library research made to strengthen the existing data related to the study.

\section{Field Research}

The library research as mentioned above will be strengthened, and supported by field research. Field research is an intensive effort to learn about the background of the current situation and a close interaction of a specific location. In this study, the chosen field is specifically the MTAQPC environment. It aims to investigate to what extent the effects of memorizing the Quran towards students' academic, co-curricular and personality achievement achieved by students of this institution. The methods used for field research in this study are questionnaires, observations and interviews.

\section{Findings}

Analysis Of SMU / SMTQ, SPM and STAM / STTQ RESULTS IN 2004

Table 1. SMU /SMTQ Results in 2004

\begin{tabular}{|l|l|c|c|c|c|c|c|c|c|c|c|}
\hline \multirow{2}{*}{ No } & \multirow{2}{*}{ Subject } & \multicolumn{9}{|c|}{ No. of students who got the score } & \multicolumn{2}{c|}{ Passed } \\
\cline { 2 - 13 } & & 1A & 2A & 3B & 4B & 5 C & 6 C & 7 D & 8E & Total & $\%$ \\
\hline 1 & Al-Quran & 9 & 4 & 0 & 1 & 3 & 3 & 2 & 7 & 29 & 90.6 \\
\hline 2 & Qiraat & 9 & 7 & 8 & 5 & 1 & 1 & 1 & 0 & 32 & 100 \\
\hline 3 & Hifzul Mutun & 28 & 4 & 0 & 0 & 0 & 0 & 0 & 0 & 32 & 100 \\
\hline 4 & Nahu \& Sorf & 20 & 7 & 1 & 0 & 0 & 3 & 1 & 0 & 32 & 100 \\
\hline 5 & Balaghah & 21 & 8 & 1 & 2 & 0 & 0 & 0 & 0 & 32 & 100 \\
\hline 6 & Mutalaah \& Insya' & 5 & 18 & 1 & 4 & 1 & 1 & 2 & 0 & 32 & 100 \\
\hline 7 & Fiqh \& Tauhid & 17 & 12 & 1 & 0 & 0 & 1 & 0 & 1 & 32 & 100 \\
\hline
\end{tabular}




\begin{tabular}{|c|l|c|c|c|c|c|c|c|c|c|c|}
\hline 8 & Tafsir \& Hadith & 21 & 6 & 2 & 1 & 2 & 0 & 0 & 0 & 32 & 100 \\
\hline 9 & Malay & 3 & 22 & 3 & 2 & 2 & 0 & 0 & 0 & 32 & 100 \\
\hline 10 & English & 0 & 3 & 5 & 7 & 5 & 0 & 8 & 1 & 32 & 100 \\
\hline
\end{tabular}

Overall results
\begin{tabular}{|l|c|c|}
\hline SMU Certificate & No & Percentage \\
\hline Excellent & 1 & 3.13 \\
\hline Grade 1 & 30 & 93.75 \\
\hline Grade 2 & 1 & 3.13 \\
\hline Grade 3 & 0 & 0 \\
\hline Fail & 0 & 0 \\
\hline Total & 32 & 100 \\
\hline
\end{tabular}

Table 1 above shows the students' performance in SMU/SMTQ examination in 2004. Students have shown good academic performance when they obtained $100 \%$ in 9 subjects which are Qiraat, Hifzul Mutun, Nahu \& Sorf, Balaghah, Mutalaah \& Insya', Fegh \& Tauhid, Tafsir and Hadith, Malay and English. Researchers found that the percentage of Quranic studies subject has dropped, which is $90.6 \%$, but all the students who sat for SMU / SMTQ examination in 2004 has succeeded in the examination.

Table 2: Certificate of Education (SPM) Results 2004

\begin{tabular}{|l|l|c|c|c|c|c|c|c|c|c|c|c|}
\hline \multirow{2}{*}{ No } & \multirow{2}{*}{ Subject } & \multicolumn{3}{|c|}{ No. of students who got the score } & \multicolumn{3}{|c|}{ Passed } \\
\cline { 2 - 13 } & 1A & 2 A & 3 B & $4 B$ & 5 C & 6 C & 7 D & 8E & 9 G & Total & $\%$ \\
\hline 1 & Malay & 5 & 14 & 7 & 3 & 1 & 1 & 0 & 0 & 0 & 31 & 100 \\
\hline 2 & English & 1 & 3 & 1 & 10 & 3 & 4 & 8 & 1 & 0 & 31 & 100 \\
\hline 3 & Mathematics & 19 & 0 & 2 & 1 & 3 & 2 & 3 & 1 & 0 & 31 & 100 \\
\hline 4 & History & 10 & 7 & 3 & 3 & 4 & 4 & 0 & 0 & 0 & 31 & 100 \\
\hline 5 & Science & 19 & 5 & 3 & 3 & 1 & 0 & 0 & 0 & 0 & 31 & 100 \\
\hline 6 & Al-Quran \& as-Sunnah Studies & 20 & 6 & 1 & 2 & 2 & 0 & 0 & 0 & 0 & 31 & 100 \\
\hline 7 & Shariah Islamiah Studies & 7 & 16 & 5 & 2 & 1 & 0 & 0 & 0 & 0 & 31 & 100 \\
\hline 8 & Advanced Arabic & 4 & 6 & 8 & 5 & 3 & 3 & 0 & 1 & 0 & 30 & 100 \\
\hline 9 & Basic Economics & 8 & 4 & 6 & 5 & 2 & 3 & 3 & 0 & 0 & 31 & 100 \\
\hline 10 & Principles of Accounting & 18 & 2 & 2 & 3 & 1 & 4 & 0 & 0 & 1 & 31 & 97 \\
\hline 11 & Additional Mathematics & 5 & 0 & 1 & 2 & 2 & 1 & 0 & 0 & 0 & 11 & 100 \\
\hline 12 & Tasawwur Islam & 0 & 1 & 1 & 0 & 0 & 0 & 0 & 0 & 0 & 2 & 100 \\
\hline
\end{tabular}

\section{Overall Results}

\begin{tabular}{|c|c|c|c|c|c|c|c|c|c|c|c|c|c|c|}
\hline Passed & 12 & 11 & 10 & $\mathbf{9}$ & $\mathbf{8}$ & $\mathbf{7}$ & $\mathbf{6}$ & $\mathbf{5}$ & $\mathbf{4}$ & $\mathbf{3}$ & $\mathbf{2}$ & $\mathbf{1}$ & Failed & Total \\
\hline No & 0 & 13 & 17 & 1 & 0 & 0 & 0 & 0 & 0 & 0 & 0 & 0 & 0 & 31 \\
\hline$\%$ & 0 & 42 & 55 & 3 & 0 & 0 & 0 & 0 & 0 & 0 & 0 & 0 & 0 & 100 \\
\hline
\end{tabular}

Table 2 above shows the students' performance in SPM examination in 2004. Students have shown good academic performance when they obtained 100\% in 11 subjects which are Malay, English, Mathematics, History, Science, Quran 
and Sunnah studies, Shariah Islamiah studies, Advanced Arabic, Basic Economics, Additional Mathematics and Tasawwur Islam.

Table 3. STAM Results in 2004

\begin{tabular}{|c|l|c|c|c|c|c|c|c|}
\hline \multirow{2}{*}{ No } & \multirow{2}{*}{ Subject } & \multicolumn{3}{|c|}{ No. of students who got the score } & \multicolumn{2}{|c|}{ Passed } \\
\cline { 2 - 9 } & & I M & JJ & J & M & R & Total & $\%$ \\
\hline 1 & Hifz Al-Quran \&Tajwid & 8 & 0 & 0 & 0 & 0 & 8 & 100 \\
\hline 2 & Figh & 5 & 2 & 1 & 0 & 0 & 8 & 100 \\
\hline 3 & Tauhid \& Mantiq & 4 & 3 & 1 & 0 & 0 & 8 & 100 \\
\hline 4 & Tafsir Wa Ulumuhu & 4 & 3 & 1 & 0 & 0 & 8 & 100 \\
\hline 5 & Hadith \& Mutalaah & 4 & 2 & 2 & 0 & 0 & 8 & 100 \\
\hline 6 & Nahu \& sorf & 5 & 1 & 2 & 0 & 0 & 8 & 100 \\
\hline 7 & Insyak \& Mutalaah & 7 & 1 & 0 & 0 & 0 & 8 & 100 \\
\hline 8 & Adab \& Nusus & 4 & 3 & 1 & 0 & 0 & 8 & 100 \\
\hline 9 & Arudh \& Qafiah & 4 & 2 & 2 & 0 & 0 & 8 & 100 \\
\hline 10 & Balaghah & 3 & 3 & 2 & 0 & 0 & 8 & 100 \\
\hline
\end{tabular}

\section{Overall Results}

\begin{tabular}{|l|c|c|}
\hline STTQ Certificate & No & Percentage \\
\hline Mumtaz & 3 & 37.5 \\
\hline Jayyid Jiddan & 1 & 12.5 \\
\hline Jayyid & 1 & 12.5 \\
\hline Maqbul & 2 & 25 \\
\hline Passed & 1 & 12.5 \\
\hline Total & 8 & 100 \\
\hline
\end{tabular}

Table 3 above shows the students' performance in STAM examination for 2004. Students have shown good academic performance when they obtained $100 \%$ in all subjects which are Hifz Al-Quran and Tajweed, Fiqh, Tawheed and Mantiq, Tafsir wa Ulumuhu, Hadith \& Mutalaah, Nahu \& Sorf, Insya' \& Mutalaah, Adab \& Nusus, Arudh \& Qafiah and Balaghah. Based on the SMU / SMTQ and STAM examination results in 2004, the researchers concluded that the students' level of academic excellence in MTAQ is excellent in all subjects. In the Malaysian Certificate of Education (SPM) 2004, results also showed that the students of MTAQ were excellent in all subjects.

\section{The Implementation of Memorization Method in MTAQPC}

All students who enroll in this tahfiz institution have finished reading the Quran according to the conditions stated for students who wish to enter this institution. It aims to ease the students' memorization of the Quran after finish reading the Quran. At least, every student can learn a little bit about the Quran in terms of the number of verses and surah in the Quran.

The MTAQPC has determined specific memorization techniques to its students in memorizing the Quran. The methods used by MTAQPC teachers when teaching Quranic memorization subject are correct pronunciation, the use of specific mushaf, regulating the rate of memorization, the recitation of dua' before memorizing and others.

Some effective methods or ways to help students to strengthen their memorization are by having good time management, providing specific time for students to revise the Quran every day as well as consuming nutritious and memory booster food from halal sources (Sawari, Ghazali, Ibrahim, \& Mustapha, 2015), such as increasing the 
consumption of raisins and zam-zam water and avoid taking shubhah food. Students should always repeat their memorization every time after praying and reading the Quran as a daily practice. Muraja'ah method and revision of the memorized verses, for instance when becoming an imam in tarawikh prayer can strengthen the memory. The method contained in the Quran are tasmi 'and through repetition during available time. The most effective method to strengthen memorization is through continuous effort to muraja'ah. This effort should come with a systematic timetable set in accordance with one's daily life. When arranging the schedule, there are several aspects need to be considered which are the most appropriate time to repeat and memorize like in the morning and at night, as well as daily or weekly for muraja'ah, and suitable situation and location. The students also must always seek help from Allah to ease and maintain their memorization because whatever efforts they make, only Allah can make them to happen based on the hadith: "I just divide and it is Allah who bestows."

In addition, students have to cultivate the feeling of love towards the Quran. Among characters that a hafiz should have are: Devotion to Allah, provide themselves with knowledge of all fields, be ethical as outlined by the Quran and the Sunnah, honest which is responsible for the memorized Quranic verses, noble, has virtues characters, humble, responsible to practice and understand the purpose of the Quran being revealed by Allah s.w.t and put it into daily practice, as well as having honourable characters from the Quran which is not just memorization alone. A hafiz also should be an intellectual, sincere to be close to Allah in the sense of a relationship between Allah and His creation, respect parents and teachers, avoid evil things and perform a lot of tahajjud. All Muslims must have these characters regardless they are hafiz or not. These characters also have been mentioned many times in the Quran and the Hadith, as well as described by the scholars especially Imam Ghazali in his books. In conclusion, a hafiz should follow what is commanded by Allah and His Prophet in his life and make Islam as a way of life and guidance. There are some specific additional characters that al-hafiz need to have in accordance with the title.

\section{Conclusion}

The results of this study have shown that the majority of the students of MTAQPC have an outstanding academic record. Researchers stated that memorizing the Quran has given a huge impact on those who memorize the Quran. This is based on the examination results obtained by students from the institution of Tahfiz al-Quran wal Qiraat Pulai Chondong, Kelantan, which consists of SMU / SMTQ, SPM, and STU / STTQ / STAM examinations. Positive achievement obtained by this tahfiz institution is the result of students' perseverance, determination and sincerity in gaining knowledge and memorizing the Quran. The researchers found that positive achievements obtained by MTAQPC are very obvious, although there were some students who were weak, the improvement every year has proven that MTAQPC can be known as an excellent tahfiz institution in this region.

\section{References}

Abdullah al-Qari Hj Salleh (1979), Keutamaan Penghafal dan Peminat al-Quran, Kota Bahru: Pustaka ASA, p. 32.

Abu Najihat al-Hafiz, (n.d), Panduan Bagi Hafiz-Hafizah \& Qari-Qariah, (t.pt): Published by Darul Iman. p.16.

Abu Najihat al-Hafiz, (t.th), Panduan Bagi Hafiz-Hafizah \& Qari-Qariah, (t.pt): Published by Darul Iman. p.16.

Al-Imam al-Hafiz Abi 'Isa Muhammad bin 'Isa bin Surah al-Tirmidhi (1975), al-Jami'al-Sahih wa huwa Sunan al-Tirmidhi, v.4, Madinah: Matba'ah,al-Fajjalah al-Jadidah, hadith no. 3069, p. 345.

Analysis of SPM results in 2004 from http://mtaq.edu.my/Analisis_keputusan_SPM_2004"

Ghazali, M. A. I., Md. Sawari, S. S., \& Yusuf, M. F. (2015). The Severity of Anti Hadith Groups (AHG) Thought: Solutions, Challenges and Barriers. Mediterranean Journal of Social Sciences, 6(3 S2), 127

Ismail Muhammad al-Muqri', Khairul Anuar Muhamad al-Bakri, (2003) Tahap-Tahap Menghafal a-Quran .Kertas Kerja VI dalam Seminar Kaedah Pengajaran dan Tahfiz al-Quran Peringkat Kebangsaan. 17 May. By Faculty of Al-Quran \& Sunnah Studies KUIM.

Ismail Muhammad al-Muqri', Khairul Anuar Muhamad al-Bakri, (2003) Tahap-Tahap Menghafal a-Quran .Kertas Kerja VI dalam Seminar Kaedah Pengajaran dan Tahfiz al-Quran Peringkat Kebangsaan. 17 May. By Faculty of Al-Quran \& Sunnah Studies KUIM.

Maahad Tahfiz Pulai Chondong (2005), Al-Hafiz,, no-8, Pulai Chondong: Al-Hafiz Editor

Masyur understanding means the memorizers or hafiz need to read the Quran in their head, have a good memory and could recite holy verses in large numbers in a short time. Their situation is different with public people.

Sawari, S. S. M., Ghazali, M. A. I., Ibrahim, M. B., \& Mustapha, N. I. (2015). Evidence Based Review on the Effect of Islamic Dietary Law Towards Human Development. Mediterranean Journal of Social Sciences, 6(3 S2), 136.

Muhaidi Hj Mustaffa Al Hafiz, Mohd Al'Ikhsan Ghazali, Siti Salwa Md. Sawari. (2015a). Eksplorasi Hubungan Hafazan Al-Quran Dan Kecemerlangan Para Pelajar Maahad Tahfiz Al-Quran Wal Qiraat Pulai Chondong. International Seminar on Educational Issues 2015. Selangor International Islamic College University.

Muhaidi Hj Mustaffa Al Hafiz, Mohd Al'Ikhsan Ghazali, Siti Salwa Md. Sawari. (2015b). Transformasi Pendidikan Hafazan Al Quran Dari 
Zaman Awal Islam Hingga Kini. International Seminar on Educational Issues 2015. Selangor International Islamic College University.

Syaykh Muhammad al-Habasyi (1987) Kayf Tahfaz al-Quran, Beirut: Dar al-Khayr, p. 131.

Yusuf al-Qardawi (n.d). al-Muraji'iyyah al-'Ulya fi al-Islam li Quran wa al-Sunnah, Kaherah: Maktabah Wahbah, p.22. 